\title{
Radiological Assessment of Cartridge 120-mm, APFSDS-T, XM829 Ammunition
}
C. D. Hooker
D. E. Hadlock
K. L. Soldat
R. L. Gilchrist

December 1983

Prepared for

Tank Ammunition Section

Munitions System Division

Large Caliber Weapons System Laboratory

Armament Research and Development Center

Pacific Northwest Laboratory

Operated for the U.S. Department of Energy

by Battelle Memorial Institute

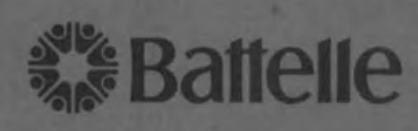




\title{
DISCLAIMER
}

This report was prepared as an account of work sponsored by an agency of the United States Government. Neither the United States Government nor any agency thereof, nor any of their employees, makes any warranty, express or implied, or assumes any legal liability or responsibility for the accuracy, completeness, or usefulness of any information, apparatus, product, or process disclosed, or represents that its use would not infringe privately owned rights. Reference herein to any specific commercial product, process, or service by trade name, trademark, manufacturer, or otherwise, does not necessarily constitute or imply its endorsement, recommendation, or favoring by the United States Government or any agency thereof. The views and opinions of authors expressed herein do not necessarily state or reflect those of the United States Government or any agency thereof.

\author{
PACIFIC NORTHWEST LABORATORY \\ operated by \\ BATTELLE \\ for the \\ UNITED STATES DEPARTMENT OF ENERGY \\ under Contract DE-AC06-76RLO 1830
}

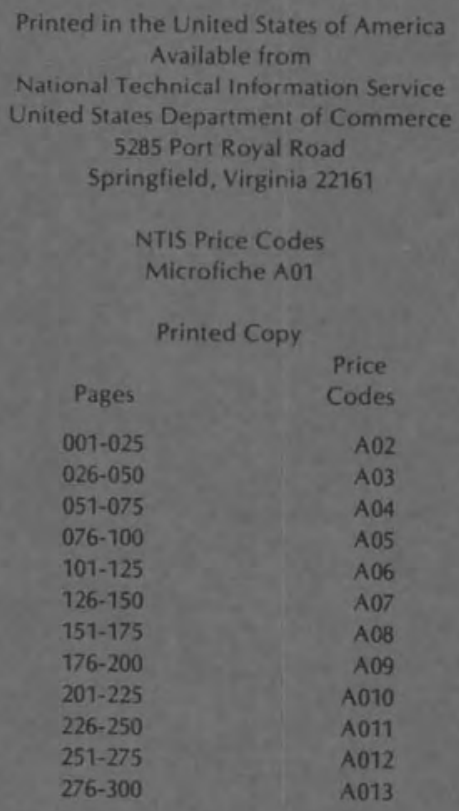


PNL -4392

UC -35

RADIOLOGICAL ASSESSMENT OF CARTRIDGE

120-mm, APFSDS-T, XM829 AMMUNITION
C. D. Hooker
D. E. Hadlock
K. L. Soldat
R. L. Gilchrist

December 1983

Prepared for

Tank Ammunition Section

Munitions System Division

Large Caliber Weapons System Laboratory

Armament Research and Development Center under a Related Services Agreement with the U.S. Department of Energy

Contract DE-AC06-76RLO 1830

Pacific Northwest Laboratory

Richlard, Washington 99352 


\section{SUMMARY}

The Department of the Army contracted with Pacific Northwest Laboratory (PNL) to investigate the health physics problems associated with the handling, shipping and storage of 120-mm, APFSDS-T, XM829 ammunition. Each round of this ammunition contains a penetrator of depleted uranium, which is classified as a radioactive source material.

The study carried out by PNL included laboratory and simulated storage analyses and an assessment of potential health physics problems. The data sought included: the characteristics of radiation emitted from a projectile; and the radiation levels emitted from a bare penetrator, projectiles, cartridges (both packaged and unpackaged), and a 16-round pallet of XM829 ammunition.

The results of the study showed the following:

- The components of the XM829 round effectively shield out nonpenetrating beta radiation emitted by the depleted uranium; however, photons can penetrate the components of the round and are therefore the predominant emission.

- The radiation levels associated with the XM829 ammunition are low. The maximum emissions measured from a cartridge are not likely to result in exposure to military personnel above the maximum permissible nonoccupational dose limits listed in Army Regulation (AR) 40-14, Control and Recording Procedures for Exposure to Ionizing Radiation and Radioactive Materials.

- Based upon the specifications contained in 49 CFR 173.424 and the radiation measurement data obtained from this study, the XM829 shipping package may be excepted from the specification packaging, marking and labeling requirements of subpart 49 CFR 173 as long as the outer surface of the uranium is enclosed in an inactive sheath and the conditions specified in 49 CFR 421 (b), (c), and (d) are met. 


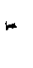




\section{CONTENTS}

SUMMARY

j j j

1.0 INTRODUCTION

2.0 TYPES OF RADIATION EMITTED BY THE XM829 AMMUNITION $. \quad . \quad . \quad 3$

3.0 RADIATION DETECTION DEVICES AND CALIBRATION TECHNIQUES • • $\quad 5$

3.1 THERMOLUMINESCENCT DOSIMETERS •

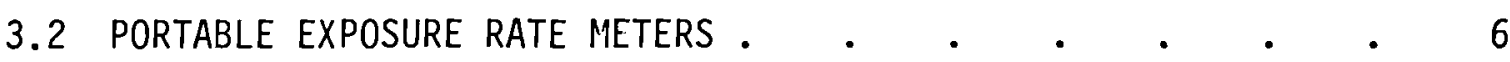

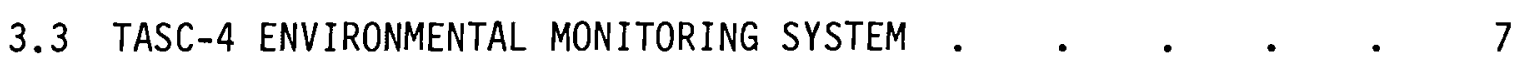

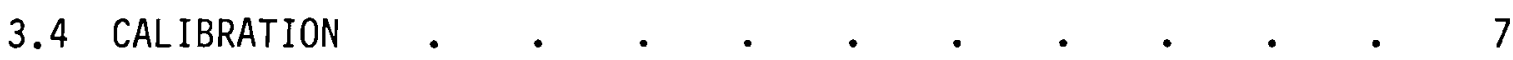

3.4.1 Thermoluminescenct Dosimeters . $\quad$ • $\quad$ • $\quad$. 7

3.4.2 Micro-R Meter . . . . . . . . . . $\quad$. 8

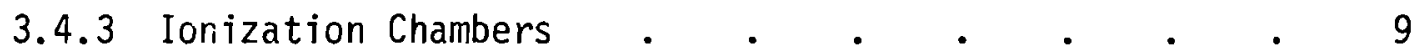

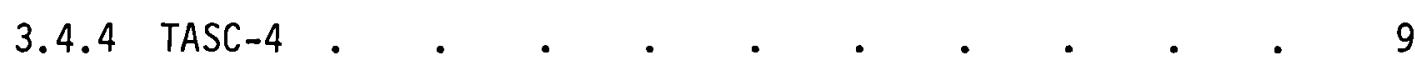

4.0 RADIATION MEASUREMENTS MADE ON THE XM829 AMMUNITION $\ldots$. $\quad$ • 11

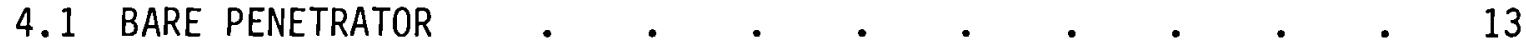

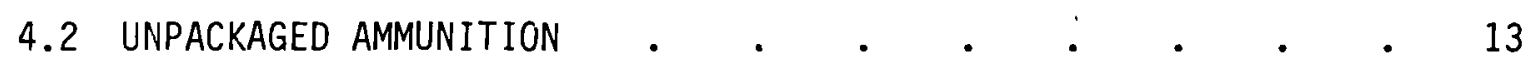

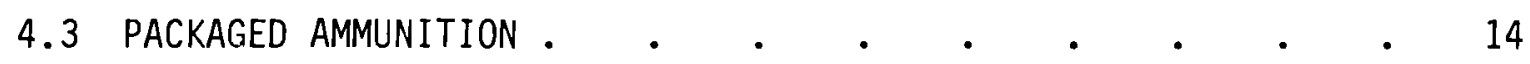

4.4 COMPARATIVE MEASUREMENTS OF XM829 and XM774 AMMUNITIONS . 17

5.0 EVALUATION OF RADIOLOGICAL HAZARD FROM MEASURED EMISSIONS • • 19

5.1 EXPOSURE OF PERSONNEL TO RADIATION FROM XM829 AMMUNITION $\quad 19$

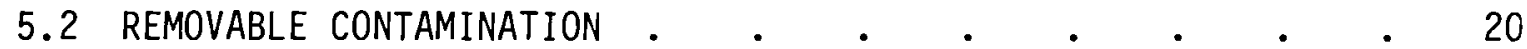

5.3 SHIPPING XM829 AMMUNITION $\quad . \quad \ldots \quad . \quad \ldots \quad . \quad \ldots \quad$. 20

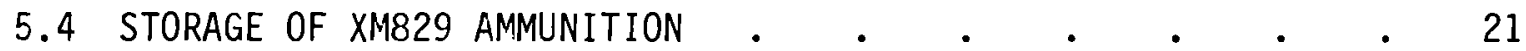

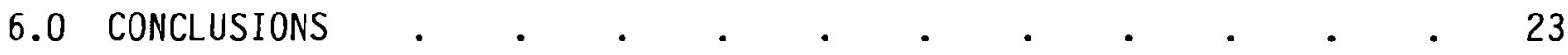

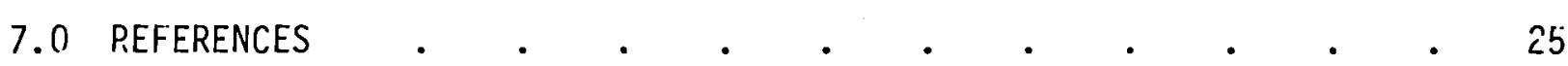

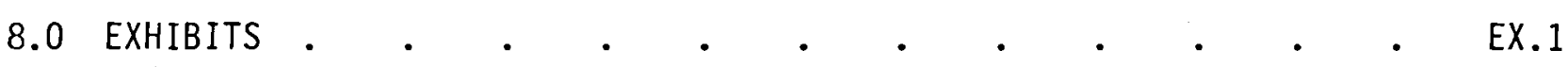





\section{TABLES}

1 Dose Limits from Federal and Army Regulations . . . . 12

2 Maximum Surface TLD Results for Exposure to the Hands from Unpackaged XM829 Ammunition . . . . . . . . . . 14

3 Portable Instrument Measurements of an XM829 Shipping Container.

4 Maximum Surface Exposure Rates and Allowable Exposure Times to the Hands from Packaged XM829 Ammunition . . . . . . 17

5 Maximum TLD Results at Distances From Pallet . . . . . . 17

6 Comparison of Radiation Measurements of XM829 and XM774 Ammunition 18

\section{FIGURES}

1 Typical Gamma Spectrum from an Assembled XM829 Projectile . .

\section{EXHIBITS}

1 TLD Measurements (nRem/hr) of Bare Penetrator . . . . EX-1

2 TLD Measurements (mR/hr) of Two Individual Projectiles . . . EX-2

3 TLD Measurements (mR/hr) of Unpackaged Cartridge . . . . EX-3

4 Micro-R Measurements $(\mathrm{mR} / \mathrm{hr}$ ) of Unpackaged Cartridge . . . EX-4

5 TASC -4 Measurements $(\mathrm{mR} / \mathrm{hr})$ of Unpackaged Cartridge . . . EX-5

6 TLD Measurements $(\mathrm{mR} / \mathrm{hr})$ of 16-Round Pallet . . . . . EX-6

7 Micro-R Measurements $(\mathrm{mR} / \mathrm{hr})$ of 16-Round Pallet . . . . . EX-7

8 TASC-4 Measurements $(\mathrm{mR} / \mathrm{hr})$ of 16-Round Pallet . . . . EX-8

9 Portable Instrument Measurement Points on Shipping Container . EX-9 
.

.

,

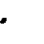

$\checkmark$ 


\subsection{INTRODUCTION}

The Department of the Army (DA) handles, stores and ships 120-mm APFSDS-T, XM829 ammunition. This ammunition has a projectile made up of a windshield, sabot, fin and penetrator. The penetrator is made up of depleted uranium (DU). A shell casing and ignition-propulsion unit are assembled to the projectile to complete the XM829 cartridge or round. Because DU is classified as a radioactive source material, the DA, through the Tank Ammunition Section, Munitions System Division, Large Caliber Weapons System Laboratory, Armament Research and Development Center (ARDC), contracted with the Pacific Northwest Laboratory $(P N L)^{(a)}$ to study and evaluate the radiological hazard associated with the ammunition.

The purpose of this study was to determine the types and levels of radiation emitted from the XM829 ammunition. The U.S. Code of Federal Regulations, Title 10, Part 20, "Standards for Protection Against Radiation" (10 CFR 20) and Army Regulation 40-14, "Control and Recording Frocedures for Exposure to Ionizing Radiation and Radioactive Materials" (AR 40-14) both list limits for radiation exposures. Title 49, Parts 171 through 179, of the Code of Federal Regulatioris (especially Parts 173.401-173.478) regulate the transportation of radioactive materials. Therefore, this study also evaluated the measured exposure rates in light of 1 ) the exposure limits for personnel given in 10 CFR 20 and AR 40-14 and 2) the shipping requirements in 49 CFR 171-179. Sections 2.0 through 5.0 of this report cover these topics as follows:

- Section 2.0--the types of radiation emitted by the XM829 ammunition

- Section 3.0--the radiation detection devices and calibration techniques used in the study

- Section 4.0--the radiation measurements made on the XM829 ammunition

- Section 5.0--evaluation of the radiological hazard from the measured emissions.

(d) Operated for the Department of Energy by Battelle Memorial Institute. 
The conclusions drawn from the study are presented in Section 6.0. Figures and diagrams showing measurement positions and results are listed in Section 8.0. 


\subsection{TYPES OF RADIATION EMITTED BY THE XM829 AMMUNITION}

Spectral measurements to determine the types of radiation emitted from ammunition with a DU penetrator were made at PNL in earlier unpublished studies of M-735E1 ammunition and in published studies of XM774 ammunition (Bartlett et. al., 1979). Some of the results of these studies are as follows:

- Beta particles constitute the predominant type of radiation emitted from bare DU penetrators.

- Gamma rays are the predominant type of radiation emitted from the assembled ammunition (projectiles and cartridges), because beta particles are largely attenuated by the windshield, sabot and fin assembly materials.

- Gamma spectrometry results do not indicate a significant photon buildup from beta interactions (Bremstralung) in the windshield, sabot or fin materials.

- The gamma spectra indicate no significant difference between the energy range of the gamma rays emitted from a bare penetrator and the energy range of those emitted from a projectile. The measurements were taken with germanium-1ithium $[\mathrm{Ge}(\mathrm{Li})]$ detectors, which are presently stateof-the-art instrumentation for gamma spectrometry.

Figure 1 shows a typical gamma spectrum from an assembled XM829 projectile. 


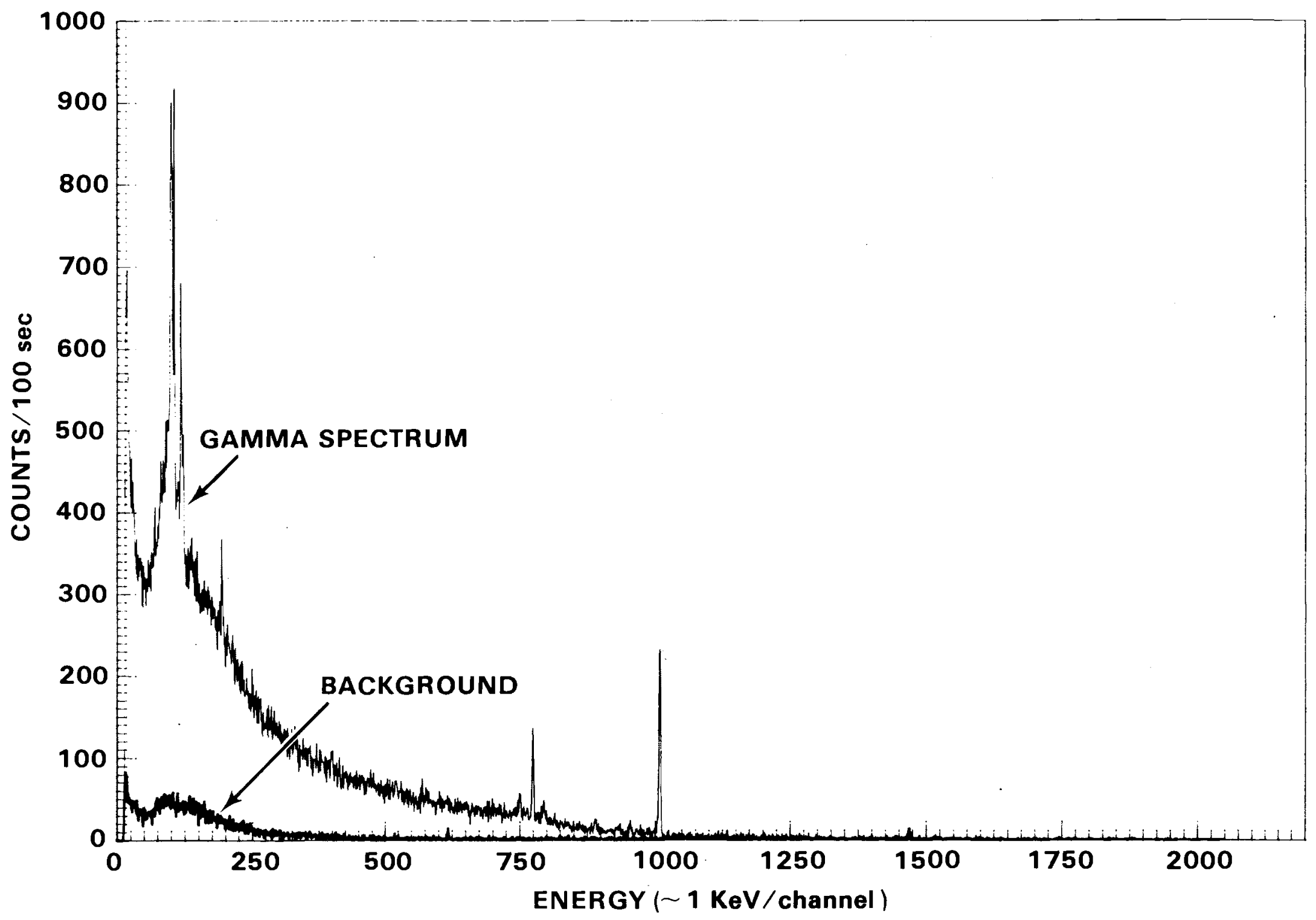

FIGURE 1. Typical Gamma Spectrum from an Assembled XM829 Projectile 


\subsection{RADIATION DETECTION DEVICES AND CALIBRATION TECHNIQUES}

Radiation levels produced by the XM829 ammunition were measured with the ammunition in various stages of assembly and packaging, and in storage configurations. The measurements were made using the following types of radiation detection devices:

1. thermoluminescent dosimeters (TLDs)

2. portable exposure rate meters

3. a semiportable monitoring system, known as the TASC-4.

The TLDs were the primary measurement device for the bare penetrator, the unpackaged single cartridge, and the multipackage pallet array. Exposure rate meters were used to substantiate these photon radiation levels and also as the primary measurement device for the packaged single cartridge. The TASC-4 system provided on-the-spot information on photon levels at points of interest being measured by the TLDs. Measurement methods and data are discussed in detail in Section 4.0 of this document.

\subsection{THERMOLUMINESCENT DOS IMETERS}

The TLDs used in this study were constructed of lithium flouride phosphor enriched in $\mathrm{Li}_{7}$ (TLD 700s), which is sensitive to both beta and gamma (photon) radiation. This material is able to trap deposited energy from ionizing radiation and store the energy in an electron lattice. When heated, the material releases a portion of the trapped energy in the form of light emissions, which can be accurately measured. The quantity of radiation absorbed in the material can be determined by comparing the amount of light emitted to the amount given

off by similar phosphors that have been exposed to a known quantity and quality of radiation.

Six thermoluminescent (TL) chips were incorporated into the dosimeter used for XM829 measurements. The chips were screened by a special process to ensure their response to within $\pm 5 \%$ of each other when exposed to the same amount of radiation under like conditions. Documented sensitivity levels for the chips were also specified in the purchase agreement with the manufacturer. 
The Dosimetry Technology Section of PNL designed a special holder which allowed three of the TL chips to be under a $0.25 \mathrm{mils}\left(6.4 \times 10^{-4} \mathrm{~cm}\right)$ mylar covered window and the other three under a $32 \mathrm{mils}(0.1 \mathrm{~cm})$ thick aluminum covered window. Beta (nonpenetrating) radiation with energies greater than or equal to that of krypton-85 (Emax $=0.67 \mathrm{Mev}$ ) were capable of penetrating the mylar window but were effectively attenuated in passing through the aluminum covered window. Most photon radiation produced by the DU was capable of penetrating both the mylar and aluminum covered windows. The difference between the responses for the two windows gave an indication of the nonpenetrating component of the delivered radiation.

The overall size of the TLD holder is approximately $1 / 2$ in. by $3 / 4 \mathrm{in}$. $(1.3 \mathrm{~cm}$ by $1.9 \mathrm{~cm})$. This small size allows the dosimeter to be placed on or close to the surfaces being measured and eliminates the need for geometry corrections. Studies have shown that TLDs have only a slight angular dependence (Kathren, Kocher, and Endres 1971).

\subsection{PORTABLE EXPOSURE RATE METERS}

Portable radiation detection instruments are commonly used to determine radiation levels emanating from radioactive shipment packages. For this reason, three types of portable instruments were used to measure the single XM829 shipping container. These were 1) a cylindrical shaped ionization chamber, 2) a rectangular shaped ionization chamber, and 3 ) an instrument which uses a 1 in. by $1 \mathrm{in.}(2.5 \mathrm{~cm}$ by $2.5 \mathrm{~cm})$ thalium-activated sodium iodide detector, $[\mathrm{NaI}(\mathrm{Tl})]$ known as the micro-R meter.

of these, ionization chambers are more frequently used to provide "field" measurements (i.e., away from the laboratory) of radioactive devices because they are 1) portable and can be easily hand carried to the measurement location, 2) they detect both gamma and beta radiations and offer capabilities for differentiating between the two radiations, and 3) they provide instantaneous readouts over an intensity range of from zero to several thousand millirem per hour.

In the micro-R meter, the detector is enclosed within the instrument case; therefore, many beta particles are attenuated by the case and do not reach the 
detector. The micro-R meter, however, is better suited for measuring very low levels of photon radiation than are the ionization chamber instruments. The intensity range of the instrument is limited to $0-3 \mathrm{mR} / \mathrm{hr}$. Radiation measured at the surfaces of the XM829 shipping package were anticipated to be predominantly low-intensity photons, approaching natural background levels at some points. Therefore, the micro-R meter was used in conjunction with the ionization chambers to obtain measurements of the shipping package.

\subsection{TASC-4 ENVIRONMENTAL MONITORING SYSTEM}

Thalium-activated sodium iodine detectors are commonly used for photon spectrometry. The variable response of the NaI ( Tl) detector system, modified for energy response, is appropriate for measurements of low photon exposure rates. Such a system is the TASC-4 environmental radiation monitoring system.

This system consists of a $2 \mathrm{in}$. by $2 \mathrm{in.}(5.1 \mathrm{~cm}$ by $5.1 \mathrm{~cm}$ ) NaI (Tl) detector coupled to a photomultiplier tube and a substantial electronics package. It is not normaliy used as a portable survey instrument. It offers greater sensitivity to photon radiation than does the micro-R meter, but like the micro-R meter, it does not detect low-energy beta radiations. The TASC -4 performs continuous, real-time monitoring of both natural and man-made gammaray (photon) emissions. Precise reliable readings of exposure rate are displayed on panel meters calibrated directly in $\mu \mathrm{R} / \mathrm{hr}$. A TASC -4 system was used in the study to provide backup information to the portable exposure rate meters and TLDs, where photon levels were expected to be low.

\subsection{CALIBRATION}

\subsubsection{Thermoluminescent Dosimeters}

The TLDs were calibrated by exposing a group of five dosimeters to selected radioactive sources that produced known exposure rates at specific distances. A natural uranium slab and a strontium-90 source were used as betaemitting sources, and a cesium-137 source was used to produce a photon, or gamma, spectrum. These sources were calibrated in the following ways: 
- natural uranium slab - An extrapolation chamber was placed close to the slab to measure the surface exposure rate.

- strontium-90 - This source was calibrated at the National Bureau of Standards (NBS) and carries a certified calibration at a source-todetector distance of $13.8 \mathrm{in} .(35 \mathrm{~cm})$.

- cesium-137 - This source was calibrated at PNL's Dosimetry Technology Laboratory using an intercomparison standard ionization chamber that carries a certified ${ }^{137}$ Cs calibration from NBS. The source-to-detector distance was $39.4 \mathrm{in} .(100 \mathrm{~cm})$.

The selection of the three sources used to calibrate the TLDs was based upon several parameters. Natural uranium was used because it produces an energy spectrum much like that of depleted uranium. Strontium-90 was used to provide another data point on the beta spectrum, which can be used to assess whether a detector's response varies with a change in the beta energy. Cesium137 is frequently used as a source to calibrate devices that detect photon radiation; the average photon energy of ${ }^{137} \mathrm{Cs}$ (662 keV) is in the range over which many detectors generally do not underrespond or overrespond. Spectral measurements show that the average photon energy from depleted uranium is approxinately 1.0 MeV (Bartlett et. al. 1979), which is also within the true response region for many detectors.

The known exposure rates produced by the sources at specified distances were used to calibrate the TLDs as follows. A group of five dosimeters, each containing three TL chips behind the beta window and three behind the gamma window, was exposed to each radioactive source. The duration of the exposure was calculated so that a known amount of radiation would be delivered to the dosimeters. The TL chips from the dosimeters were then read out, and the readings were averaged for all 15 chips from each dosimeter position. This value was then compared to the delivered exposure value, and the ratic became the calibration factor for that radiation energy.

\subsubsection{Micro-R Meter}

The portable micro-R meter was calibrated to NBS traceable ${ }^{137}$ Cs and 830 keV ${ }^{226} \mathrm{Ra}$ (ATTIX, Roesch, Tochilin 1969) sources at the PNL Instrument 
Calibrations Laboratory. Cesium-137 was used as the field check source. With the ${ }^{137}$ Cs check source at contact with the detector housing, the instrument gave a reading of $160 \mu \mathrm{R} / \mathrm{hr}$. Source activity was $0.940 \mu \mathrm{Ci}$.

\subsubsection{Ionization Chambers}

Both the cylindrical and rectangular shaped ionization chambers were calibrated to NBS traceable ${ }^{137}$ Cs sources at the PNL Instrument Calibrations Laboratory.

\subsubsection{TASC -4}

The TASC-4 system was calibrated to both a $356 \mathrm{keV}{ }^{133} \mathrm{Ba}$ source and a 662 keV ${ }^{137}$ Cs source for photon energy response. A ${ }^{137}$ Cs source of known activity was used as a field check source. 



\subsection{RADIATION MEASUREMENTS MADE ON THE XM829 AMMUNITION}

Radiation levels produced by the XM829 ammunition were measured with the ammunition in various stages of assembly and packaging, and in a simulated storage array. The measurements were made at two locations: 1) emissions from the bare penetrator and from two unpackaged projectiles were measured at PNL's Dosimetry Technology Laboratory in Richland, Washington; and 2) emissions from an unpackaged cartridge, a packaged cartridge in a shipping box, and a pallet load of 16 cartridges (each individually packaged and boxed) were made in Building 1089 at the Aberdeen Proving Ground (APG) in Aberdeen, Maryland. At both locations, background measurements were taken to document the response of the detectors to ambient radiation levels.

All of the radiation detection devices discussed in Section 3.0, TLDs, portable exposure rate meters, and the TASC-4 environmental monitoring system, were used to measure the radiation emitted from the XM829 ammunition. Exposure rates that were based on TLD measurements were calculated from the total measured exposure by dividing by the exposure time. All of the other instruments had direct exposure rate-per-time readout capabilities. The TLD data were used to report direct surface measurements of the unpackaged, assembled and unassembled XM829, as well as for the 16 round pallet for the following reasons:

- These dosimeters were able to measure all aspects of the radiation emitted from the ammunition. They are sensitive to both photon and beta radiation, and because of their small size, they could be placed at all measurement locations.

- Because the TLDs could be placed directly on the surfaces of the ammunition and packages, the TLD readings did not have to be corrected for angular dependence, measurements could be taken in a consistent manner at all locations, and the resulting data provided reliable exposure information.

- The calibration of the TLDs was directly traceable to the NBS. Portable instruments were used to measure the shipping package because they are more commonly used for that purpose than are TLDs. 
Measurement data were also used to calculate the maximum allowable exposure times for personnel handling the ammunition. A factor that affects the determination of maximum allowable exposure times is the dose limit below which exposures must be maintained. A comparison of the occupational dose limits set by the U.S. Code of Federal Regulations (in 10 CFR 20) and the U.S. Army (in AR 40-14) is given in Table 1. The nonoccupational dose limits set by the Army are one-tenth of the occupational dose limits given in AR 40-14.

TABLE 1. Dose Limits From Federal and Army Regulations

\begin{tabular}{|c|c|c|c|}
\hline Part of the Body & & $\begin{array}{l}\text { Quarterly and Annual } \\
A R \quad 40-14\end{array}$ & $\frac{\frac{1}{\text { ccupational Dose Limits }}}{10 \text { CFR } 20}$ \\
\hline Whole Body & $\begin{array}{l}\text { (a) } \\
\text { (b) }\end{array}$ & $\begin{array}{l}1.25 \mathrm{rems} / \mathrm{cal} \mathrm{qtr} \\
5 \mathrm{rems} / \mathrm{cal} \mathrm{yr}\end{array}$ & $\begin{array}{l}1.25 \mathrm{rems} / \mathrm{cal} \text { qtr } \\
5(\mathrm{~N}-18) \mathrm{rems} / \mathrm{cal} \text { yr }(\mathrm{a})\end{array}$ \\
\hline Hands & $\begin{array}{l}\text { (a) } \\
\text { (b) }\end{array}$ & $\begin{array}{l}18.75 \mathrm{rems} / \mathrm{cal} \mathrm{qtr} \\
75.0 \mathrm{rems} / \mathrm{cal} \mathrm{yr}\end{array}$ & $\begin{array}{l}18.75 \mathrm{rems} / \mathrm{cal} \mathrm{qtr} \\
75.0 \mathrm{rems} / \mathrm{cal} \mathrm{yr}\end{array}$ \\
\hline Forearms & $\begin{array}{l}\text { (a) } \\
\text { (b) }\end{array}$ & $\begin{array}{l}10 \mathrm{rems} / \mathrm{cal} \mathrm{qtr} \\
30 \mathrm{rems} / \mathrm{cal} \mathrm{yr}\end{array}$ & $\begin{array}{l}18.75 \text { rems } / \text { cal gtr } \\
75 \text { rems } / \text { cal yr }\end{array}$ \\
\hline $\begin{array}{l}\text { Skin (other than hands } \\
\text { and forearms) }\end{array}$ & $\begin{array}{l}\text { (a) } \\
\text { (b) }\end{array}$ & $\begin{array}{l}7.5 \mathrm{rems} / \mathrm{cal} \mathrm{qtr} \\
30 \mathrm{rems} / \mathrm{cal} \mathrm{yr}\end{array}$ & $\begin{array}{l}7.5 \mathrm{rems} / \mathrm{cal} \mathrm{qtr} \\
30 \mathrm{rems} / \mathrm{cal} \mathrm{yr}\end{array}$ \\
\hline
\end{tabular}

(a) Where " $N$ " equals the individual's age in years at his last birthday.

Because the dose limits in Ar 40-14 are more restrictive than those in 10 CFR 20, allowable exposure times were calculated based on the dose limits in AR 40-14. Exposure times were calculated for hand, forearm, and whole-body exposures assuming contact with the surface of each configuration of the ammunition. Some exposure times were also calculated for personnel at a distance from the ammunition.

The exposure rates measured and the maximum allowable exposure times determined from the measured rates are discussed in the following sections for a bare DU penetrator and for unpackaged and packaged ammunition. 


\subsection{BARE PENETRATOR}

The locations and results of TLD measurements of a bare DU penetrator are shown in Exhibit 1. Measurements were taken both at the surface of the penetrator and at a distance of $3.3 \mathrm{ft}(1 \mathrm{~m})$ parallel to it.

The surface of the penetrator was found to produce exposure rates averaging $243 \pm 21.4 \mathrm{mrem} / \mathrm{hr}$. Of this amount, the beta (nonpenetrating) component measured $217 \pm 20.4 \mathrm{mrem} / \mathrm{hr}$, and the gamma (penetrating) component measured $26.0 \pm 2.7 \mathrm{mR} / \mathrm{hr}$. The open literature shows that natural uranium slabs typically produce beta surface dose rates of approximately $233 \mathrm{mrem} / \mathrm{hr}$ through 7 $\mathrm{mg} / \mathrm{cm}^{2}$ of mylar (Radiological Health Handbook 1970). These data indicate that the bare DU penetrator produces dose rates much like those of natural uranium and that the nonpenetrating component is predominant.

The maximum exposure rate reading from eight dosimeters placed $3.3 \mathrm{ft}$ (1 1 : ) from the penetrator was $0.660 \mathrm{mR} / \mathrm{hr}$. At this rate, 757 hours of exposure would be required for an individual to receive the annual nonoccupational whole-body dose limit of 0.5 rem as set by AR 40-14.

\subsection{UNPACKAGED AMMUNITION}

The unpackaged ammunition, two single projectiles and a single cartridge, yielded measured surface exposure rates that were considerably lower than those of the bare penetrator. A reduction in the exposure rate was to be expected based upon the attenuation of the radiation emitted from the penetrator by components such as the fins, windshield and sabot. TLD surface measurements resulted in exposure rate patterns that were similar for the two projectiles, although the miaximum exposure rates were different $(18.6 \mathrm{mR} / \mathrm{hr}$ and $22.9 \mathrm{mR} / \mathrm{hr}$, respectively; see Exhibit 2 ). In both cases, the windshield area yielded the highest exposure rates.

The maximum exposure rate determined by a TLD at the surface of the single cartridge $(6.3 \mathrm{mR} / \mathrm{hr}$, see Exhibit 3$)$ was also from the windshield area, although the reading was much lower than the projectile readings (see Exhibit 3 for TLD data, Exhibit 4 for Micro-R data, and Exhibit 5 for TASC-4 data). These data indicate that the addition of the ignition-propulsion unit to a projectile results in a significant reduction in the exposure rate at the 
windshield area. A review of the measurements taken of the XM774 ammunition indicates a similar difference between the windshield area readings for the projectile and the cartridge (See Section 4.4).

Table 2 shows the maximum surface exposure rates to the hands measured from the unpackaged XM829 ammunition, and the calculated allowable nonoccupational exposure times. These times are based on the limits in AR 40-14 and the maximum exposure rate for each configuration. The annual 7 imits established in AR 40-14 are: 7.5 rem to the hands, 3.0 rem to the forearms and 0.5 rem to the whole body.

TABLE 2. Maximum Surface TLD Results for Exposure to the Hands from Unpackaged XM829 Ammunition

\begin{tabular}{|c|c|c|c|}
\hline Source & Location & $\begin{array}{l}\text { Maximum } \\
\text { Exposure } \\
\text { Rate, mR/hr }\end{array}$ & $\begin{array}{l}\text { Maximum Allowable } \\
\text { Exposure Time, hr }\end{array}$ \\
\hline Projectile & Windshield & 22.9 & 327.5 \\
\hline Single Cartridge & Windshield & 6.3 & $1,190.5$ \\
\hline
\end{tabular}

The forearm and whole body exposure limits may also be used with the measured maximum surface exposure rates to calculate an allowable exposure time. This calculation is only valid if the rounds are either in contact with the forearms or an area of the whole body such as the chest. One possibility for this configuration would be the cradling of a round when moved by personnel.

Exposure measurements were taken at $3.3 \mathrm{ft}(1 \mathrm{~m})$ from the projectiles; 10 TLDs were positioned parallel to each of the two rounds (see Exhibit 2). The maximum 1-m measurement for the two projectiles was $0.095 \mathrm{mR} / \mathrm{hr}$, and the average measurements were $0.080 \mathrm{mR} / \mathrm{hr}$ and $0.074 \mathrm{mR} / \mathrm{hr}$, respectively. Based on the maximum value at $1 \mathrm{~m}$, it would require 5263 hours of exposure to reach the $A R$ 40-14 limit for nonoccupational dose to the whole body.

\subsection{PACKAGED AMMUNITION}

The locations at which radiation measurements were taken on the surfaces of a 16-round pallet are shown in Exhibits 6, 7, and 8 respectively. The 
results of these measurements in $\mathrm{mR} / \mathrm{hr}$ are also shown. Measurements of the single boxed cartridge were made with three portable exposure rate instruments ( 2 ionization chambers and 1 micro-R meter). Survey points are shown in Exhibit 9 and $\mathrm{mR} / \mathrm{hr}$ values are shown in Table 3 . An analysis of the data indicates that exposure rates at all surfaces of the packaged ammunition do not constitute a significant radiological hazard. The maximum surface exposure rates measured for each configuration are:

- 16-round pallet

$0.867 \mathrm{mR} / \mathrm{hr}$

- single boxed cartridge

$0.400 \mathrm{mR} / \mathrm{hr}$.

TABLE 3. Portable Instrument Measurements of anXM829 Shipping Container(a)

\section{SIDES}

\begin{tabular}{|c|c|c|c|c|c|c|c|c|c|}
\hline \multirow[b]{2}{*}{ Position } & \multicolumn{3}{|c|}{ Top } & \multicolumn{3}{|c|}{ Front } & \multicolumn{3}{|c|}{ Back } \\
\hline & $A$ & $\mathrm{~B}$ & $C$ & $A$ & B & $\mathrm{C}$ & $A$ & $\mathrm{~B}$ & $C$ \\
\hline 1 & 0.02 & 0.1 & 0.1 & 0.02 & 0.1 & 0.1 & 0.02 & 0.1 & 0.1 \\
\hline 2 & 0.03 & 0.1 & 0.1 & 0.03 & 0.1 & 0.1 & 0.02 & 0.1 & 0.1 \\
\hline 3 & 0.07 & 0.1 & 0.1 & 0.07 & 0.1 & 0.1 & 0.08 & 0.1 & 0.1 \\
\hline 4 & 0.15 & 0.1 & 0.1 & 0.17 & 0.1 & 0.1 & 0.19 & 0.2 & 0.2 \\
\hline 5 & 0.22 & 0.1 & 0.1 & 0.26 & 0.1 & 0.2 & 0.30 & 0.2 & 0.3 \\
\hline 6 & 0.24 & 0.1 & 0.2 & 0.27 & 0.2 & 0.3 & 0.40 & 0.3 & 0.3 \\
\hline 7 & 0.21 & 0.1 & 0.2 & 0.24 & 0.2 & 0.2 & 0.30 & 0.3 & 0.3 \\
\hline 8 & 0.13 & 0.1 & 0.1 & 0.14 & 0.1 & 0.2 & 0.18 & 0.2 & 0.2 \\
\hline 9 & 0.06 & 0.1 & 0.1 & 0.07 & 0.1 & 0.1 & 0.07 & 0.1 & 0.1 \\
\hline 10 & 0.01 & 0.1 & 0.1 & 0.02 & 0.1 & 0.1 & 0.03 & 0.1 & 0.1 \\
\hline 11 & 0.03 & 0.1 & 0.1 & 0.03 & 0.1 & 0.1 & 0.04 & 0.1 & 0.1 \\
\hline 12 & 0.07 & 0.1 & 0.1 & 0.07 & 0.1 & 0.1 & 0.08 & 0.1 & 0.1 \\
\hline 13 & 0.16 & 0.1 & 0.1 & 0.19 & 0.1 & 0.2 & 0.18 & 0.1 & 0.2 \\
\hline 14 & 0.29 & 0.2 & 0.2 & 0.30 & 0.2 & 0.3 & 0.40 & 0.2 & 0.3 \\
\hline 15 & 0.35 & 0.2 & 0.2 & 0.35 & 0.2 & 0.4 & 0.40 & 0.2 & 0.4 \\
\hline 16 & 0.30 & 0.2 & 0.2 & 0.30 & 0.2 & 0.3 & 0.40 & 0.3 & 0.3 \\
\hline 17 & 0.13 & 0.1 & 0.1 & 0.15 & 0.1 & 0.2 & 0.20 & 0.2 & 0.2 \\
\hline 18 & 0.06 & 0.1 & 0.1 & 0.07 & 0.1 & 0.2 & 0.07 & 0.1 & 0.1 \\
\hline 19 & 0.02 & 0.1 & 0.1 & 0.02 & 0.1 & 0.1 & 0.03 & 0.1 & 0.1 \\
\hline 20 & 0.03 & 0.1 & 0.1 & 0.04 & 0.1 & 0.1 & 0.04 & 0.1 & 0.1 \\
\hline 21 & 0.07 & 0.1 & 0.1 & 0.08 & 0.1 & 0.1 & 0.08 & 0.2 & 0.1 \\
\hline 22 & 0.15 & 0.1 & 0.1 & 0.17 & 0.1 & 0.1 & 0.17 & 0.2 & 0.2 \\
\hline 23 & 0.23 & 0.2 & 0.2 & 0.26 & 0.1 & 0.2 & 0.29 & 0.2 & 0.3 \\
\hline
\end{tabular}

Distance Measurements (maximum)

$\frac{3 \text { feet }}{0.09} \frac{3}{0.03}$

(a) All values in $\mathrm{mR} / \mathrm{hr}$. 
TABLE 3. (contd)

SIDES (contd)

\begin{tabular}{|c|c|c|c|c|c|c|c|c|c|}
\hline \multirow[b]{2}{*}{ Position } & \multicolumn{3}{|c|}{ Top } & \multicolumn{3}{|c|}{ Frolit } & \multicolumn{3}{|c|}{ Back } \\
\hline & $\bar{A}$ & $B$ & $c$ & $\bar{A}$ & $\mathrm{~B}$ & $C$ & A & $\bar{B}$ & C \\
\hline 24 & 0.25 & 0.2 & 0.2 & 0.28 & 0.1 & 0.2 & 0.29 & 0.2 & 0.3 \\
\hline 25 & 0.22 & 0.1 & 0.1 & 0.24 & 0.1 & 0.2 & 0.30 & 0.2 & 0.3 \\
\hline 26 & 0.14 & 0.1 & 0.1 & 0.14 & 0.1 & 0.2 & 0.15 & 0.1 & 0.2 \\
\hline 27 & 0.06 & 0.1 & 0.1 & 0.07 & 0.1 & 0.1 & 0.07 & 0.1 & 0.1 \\
\hline
\end{tabular}

ENDS

\begin{tabular}{|c|c|c|c|c|c|c|}
\hline & \multicolumn{3}{|c|}{ Front } & \multicolumn{3}{|c|}{ Back } \\
\hline & A & B & C & A & $\mathrm{B}$ & $C$ \\
\hline 28 & 0.04 & 0.1 & 0.1 & 0.01 & 0.1 & 0.1 \\
\hline 29 & 0.05 & 0.1 & 0.1 & 0.01 & 0.1 & 0.1 \\
\hline 30 & 0.04 & 0.1 & 0.1 & 0.01 & 0.1 & 0.1 \\
\hline 31 & 0.04 & 0.1 & 0.1 & 0.01 & 0.1 & 0.1 \\
\hline 32 & 0.05 & 0.1 & 0.1 & 0.01 & 0.1 & 0.1 \\
\hline 33 & 0.04 & 0.1 & 0.1 & 0.02 & 0.1 & 0.1 \\
\hline 34 & 0.04 & 0.1 & 0.1 & 0.02 & 0.1 & 0.1 \\
\hline 35 & 0.04 & 0.1 & 0.1 & 0.02 & 0.1 & 0.1 \\
\hline 36 & 0.04 & 0.1 & 0.1 & 0.02 & 0.1 & 0.1 \\
\hline
\end{tabular}

Distance Measurements (maximum)

$\frac{1 \text { foot }}{0.09}$

A. Micro-R

B. Cylindrical lon Chamber

C. Rectangular Ion Chamber

(a) All values in $\mathrm{mR} / \mathrm{hr}$.

Table 4 lists, for each package configuration, the amount of accrued exposure time that would result in the annual nonoccupational dose limit listed in AR 40-14 for the hands using the maximum measured exposure rates for the packaged XM829 ammunition.

In addition to the determination of surface exposure rates, distarice exposure measurements were taken by placing TLDs at 18 in. $(45.7 \mathrm{~cm}), 36$ in. $(91.4$ $\mathrm{cm})$, and $72 \mathrm{in.}(182.9 \mathrm{~cm})$ from one side and one end of the 16-round pallet. Table 5 is a listing of the maximum exposure rates determined and the allowable nonoccupational time limits at these distances for whole body exposure. 
TABLE 4. Maximum Surface Exposure Rates and Allowable Exposure Times to the Hands from Packaged XM829 Ammunition

\begin{tabular}{|c|c|c|}
\hline Source & $\begin{array}{l}\text { Maximum } \\
\text { Exposure } \\
\text { Rate, mR/hr } \\
\end{array}$ & $\begin{array}{l}\text { Maximum Allowable } \\
\text { Exposure Time, hr }\end{array}$ \\
\hline Single Boxed Cartridge & 0.400 & 18,750 \\
\hline 16-Round $\mathrm{Pallet}$ & 0.867 & 8,651 \\
\hline
\end{tabular}

TABLE 5. Maximum TLD Results at Distances From Pallet

\begin{tabular}{|c|c|c|c|c|}
\hline Source & $\begin{array}{c}\text { Distance, } \\
\text { in. } \\
\end{array}$ & $\begin{array}{l}\text { Maximum } \\
\text { Exposure } \\
\text { Rate, } m R / h r \\
\end{array}$ & $\begin{array}{l}\text { Annual Nonoccupa- } \\
\text { tional Whole (Bgdy } \\
\text { Limit, rem }\end{array}$ & $\begin{array}{l}\text { Maximum } \\
\text { Allowable } \\
\text { Exposure } \\
\text { Time, hr } \\
\end{array}$ \\
\hline $\begin{array}{l}\text { 16-Round Pallet } \\
\text { (Side) }\end{array}$ & $\begin{array}{l}18 \\
36 \\
72\end{array}$ & $\begin{array}{l}0.267 \\
0.089 \\
0.022\end{array}$ & $\begin{array}{l}0.5 \\
0.5 \\
0.5\end{array}$ & $\begin{array}{r}1,872 \\
5,618 \\
22,727\end{array}$ \\
\hline $\begin{array}{l}\text { 16-Round Pallet } \\
\text { (End) }\end{array}$ & $\begin{array}{l}18 \\
36 \\
72\end{array}$ & $\begin{array}{l}0.200 \\
0.044 \\
0.044\end{array}$ & $\begin{array}{l}0.5 \\
0.5 \\
0.5\end{array}$ & $\begin{array}{r}2,500 \\
11,363 \\
11,363\end{array}$ \\
\hline
\end{tabular}

(a) From Ar 40-14.

\subsection{COMPARATIVE MEASUREMENTS OF XM829 AND XM774 AMMUNITIONS}

The radiation measurement data taken from the XM1829 and the XM774 (Bartlett et. a1., 1979) ammunitions were compared. Mariy more data points were available from the packaged (boxed) portion of the XM829 study than from the XM774 study, both for single boxed cartridges and for multiround pallet configurations. The numbers of measurement points for unpackaged ammunition were more closely equated. A comparison of the data for the two types of ammunition is shown in Table 6.

The maximum exposure rates measured in the windshield area of the unpackaged cartridges and the single packaged cartridges are similar. In contrast, there is a large difference in the windshield area measurements of the 
TABLE 6. Comparison of Radiation Measurements of XM829 and XM774 Ammunition

\begin{tabular}{|c|c|c|c|}
\hline \multirow[b]{2}{*}{ Source } & \multirow[b]{2}{*}{ Position } & \multicolumn{2}{|c|}{ Maximum Exposure Rate, $\mathrm{mR} / \mathrm{hr}(\mathrm{a})$} \\
\hline & & XM829 & $\mathrm{XM774}(\mathrm{b})$ \\
\hline Bare Penetrator & $\begin{array}{l}\text { (Maximum) } \\
\text { (Average) }\end{array}$ & $\begin{array}{l}272 \mathrm{mrem} / \mathrm{hr} \\
243 \pm 21.4 \mathrm{mrem} / \mathrm{hr} \\
\text { (includes } 26 \mathrm{mR} / \mathrm{hr} \text { ) }\end{array}$ & $\begin{array}{l}247 \mathrm{mrem} / \mathrm{hr} \\
214 \pm 17.0 \mathrm{mrem} / \mathrm{hr} \\
\text { (gamma component not } \\
\text { available) }\end{array}$ \\
\hline $\begin{array}{l}\text { Single Projectile } \\
\text { (Unpackaged) }\end{array}$ & Windshield & 22.9 & 59.5 \\
\hline $\begin{array}{l}\text { Single Cartridge } \\
\text { (Unpackaged) }\end{array}$ & Windshield & 6.3 & 5.358 \\
\hline $\begin{array}{l}\text { Single Cartridge } \\
\text { (Packaged) }\end{array}$ & $\begin{array}{l}\text { Top } \\
\text { Side } \\
\text { End }\end{array}$ & $\begin{array}{l}0.350 \\
0.400 \\
0.045\end{array}$ & $\begin{array}{l}0.29 \\
0.4 \\
0.02\end{array}$ \\
\hline Pallet (Packaged) & $\begin{array}{l}\text { Top } \\
\text { Side } \\
\text { End }\end{array}$ & $\begin{array}{l}0.867 \\
0.800 \\
0.378\end{array}$ & $\begin{array}{l}0.229 \\
0.583 \\
0.145\end{array}$ \\
\hline
\end{tabular}

(a) Units in $\mathrm{mR} / \mathrm{hr}$ except where noted.

(b) Data source: Bartlett et. al. 1979.

unpackaged single projectiles, without the ignition-propulsion system attached. The exposure rates from the XM829 ammunition are considerably lower than those from the XM774 ammunition for the unpackaged projectiles. This is the result of the full encasement of the DU penetrator on the XN829; the XM774 did not have a fully encased penetrator. The increased exposure rates from the XM829 pallet reflect the increased amount of DU material in that round as compared to the $X M 774$. 


\subsection{EVALUATION OF RADIOLOGICAL HAZARD FROM MEASURED EMISSIONS}

The PNL study provided information that can be used to evaluate the radiological hazard to personnel handling the XM829 ammunition and to determine whether federal and Army regulations are complied with in the handling and shipping of the ammunition. Both 10 CFR 20 and AR 40-14 (which is also designated regulation DLAR 1000.28 of the Defense Logistics Agency) prescribe permissible dose levels and concentration standards. The standards in 10 CFR 20 apply to Nuclear Regulatory Commission licensees. The standards in AR 40-14 implement the guidelines in 10 CFR 20 and regulate the exposure of personnel (military and civilian, federal and nonfederal) to ionizing radiation at installations of the Department of the Army or the Defense Logistics Agency. As previously discussed, the occupational and nonoccupational dose limits set in AR 40-14 are more restrictive than those in 10 CFR 20. The shipping of radioactive materials is regulated by 49 CFR 171-179 (especially Parts 173.401-173.478).

\subsection{EXPOSURE OF PERSONNEL TO RADIATION FROM XM82.9 AMMUNITION}

The maximum exposure rates shown in Section 4.0 were based on actual measurements, and were calculated from total measured dose per unit time. Several factors affect how these exposure rates relate to personnel working with the ammunition:

- the low probability of personnel being exposed to the DU material in each measurement array

- the low probability of personnel remaining for a significant time near the localized areas at which the maximum exposure rates were measured

- the low probability of personnel receiving whole-body exposures, for which dose limits are the most restrictive.

Considering these factors, and considering that the dose limits used to determine maximum allowable exposure times were the most restrictive (the guidelines in AR 40-14 for nonoccupational exposures allow only one-tenth of the permissible occupational exposures), the assumptions used in this study to assess the radiation hazard to personnel handling the XM829 ammunition could be said to represent worst-case situations. Therefore, no significant problem 
is anticipated in maintaining exposure to personnel at levels below those spelled out in AR 40-14, and in complying with the philosophy of reducing and maintaining exposures to as low as reasonably achievable.

\subsection{REMOVABLE CONTAMINATION}

During the study of the XM829 ammunition, a bare DU penetrator was handled in the laboratory. Cotton gloves were worn and were surveyed for possible loose contamination from the penetrator. (Cotton gloves used in handling poteritially contaminated material can be very effective as a "smear" or "swipe" medium.) No contamination was detected. Further, personnel working with the XM829 ammunition in all phases of this study were monitored for possible contamination. No contamination was detected throughout the project. Nevertheless, personnel handling bare DU penetrators should wear cotton or leather gloves and perform periodic personal surveys as a precautionary measure.

\subsection{SHIPFING XM829 AMMUNITION}

Army regulation AR 40-14 refers to 49 CFR 171-179 (Department of Transportation (DOT), "Hazardous Materials Regulations") as the criteria for shipping radioactive materials. Requirements for the packaging and transport of such materials are given in 49 CFR 171-179 (DOT requirements).

Revisions to requirements of Hazardous Materials Regulations concerning radioactive materials became effective July 1, 1983. A review of the data collected from this study, in light of these revisions, indicates that the XM829 shipping package should be transported under the specifications listed in 49 CFR 173.424, "Excepted Articles Containing Natural Uranium or Thorium." These specifications are:

"Manufactured articles in which the sole radioactive material content is natural or depleted uranium or natural thorium are excepted from the specification packaging, marking and labeling requirements of this subchapter and requirements of this subpart if --

(a) The outer surface of the uranium or thorium is enclosed in an inactive sheath made of metal or other protective material; and 
(b) The conditions specified in 173.421 (b), (c), and (d) are met."

The conditions specified in 49 CFR 173.421 are as follows:

"(b) The radiation level at any point on an external surface of the package does not exceed 0.5 millirem per hour.

(c) The nonfixed (removable) radioactive surface contamination on the external surface of the package does not exceed the limits specified in 173.443(a)." Which are:

(1) for beta-gamma emitting radionuclides; all radionuclides with half1 ives less than 10 days; natural uranium; natural thorium; uranium-235; uranium-238; thorium-232; thorium-228; and thorium-230 when contained in ores or physical concentrates; the maximum permissible limits are $10^{-5} \mu \mathrm{Ci} / \mathrm{cm}^{2}$ or $22 \mathrm{dpm} / \mathrm{cm}^{2}$, and

(2) for all other alpha emitting radionuclides the maximum permissible limits are $10^{-6} \mu \mathrm{Ci} / \mathrm{cm}^{2}$ or $2.2 \mathrm{dpm} / \mathrm{cm}^{2}$ when averaged over a surface area of 300 square centimeters.

"(d) The outside of the inner packaging or if there is no inner packaging, the outside of the packaging itself bears the marking "Radioactive."

The depleted uranium penetrator employed in the XM829 cartridge is fully enclosed within an inactive metal sheath. The maximum radiation level obtained at any point on the external surface of the shipping package from the study was 0.4 millirem per hour. No removeable contamination was detected from "swipes" taken of the penetrator and component parts throughout the study. Based upon these factors, all criteria listed in 49 CFR 173.424 and 49 CFR 173.421 (b), (c), and (d) are satisfied by the XM829 shipping package, providing that the word "Radioactive" is stenciled on the inner or outer container.

\subsection{STORAGE OF XM829 AMMUNITION}

Radiation measurements were taken of a 16 -round XM829 pallet array simulating a storage configuration. A typical storage array may consist of several pallets; however, reasonable coriclusions may be drawn, concerning exposure rates at other points of interest, by using the single pallet measurement data. 
Due to the physical dimensions of the pallet array, only a limited number of additional pallets may be positioned closely enough to contribute significantly to the exposure rate at any one position. For example, if pallets were divided along each perimeter by a 3 -ft wide aisle, the radiation measurement at the center point in the aisle would largely reflect the contribution from only two pallets. If pallets along each side of the aisle were stored end to end, thus forming a solid wall along each side, it is conceivable that four pallets may contribute equally to the exposure rate at some central point among them.

Based upon this study, the maximum radiation measurement at 18 inches from the pallet was $0.340 \mathrm{mR} / \mathrm{hr}$. From this information it can be assumed that a person standing 18 inches equidistant from 4 pallets would be exposed to approximately $1.4 \mathrm{mR} / \mathrm{hr}$. At this rate, it would require 357 hours of exposure to receive the maximum allowable nonoccupational whole-body dose of $500 \mathrm{mrem}$, as specified in AR 40-14. 


\subsection{CONCLUSIONS}

The predominant radiations emitted from the assembled XM829 cartridge were shown to be photons with a family of energies. The most prominent energy peaks were noted in the $100 \mathrm{keV}$ to $200 \mathrm{keV}$ range; however, these photon energies are largely attenuated by the shipping/storage package materials. Therefore, energy peaks at approximately $775 \mathrm{keV}$ and $1000 \mathrm{keV}$, respectively, rema in as the most prominent photons reaching the exterior surfaces of the shipping/ storage container.

The PNL studies indicate that the radiation levels associated with the assembled XM829 ammunition, both packaged and unpackaged, are very low. A worker would have to be exposed to packaged ammunition for at least $577 \mathrm{hr}$ in order to receive the most restrictive annual, nonoccupational dose permitted by AR 40-14. This exposure time is for the top of a 16-round pallet and assumes direct whole-body contact with the surface of the pallet at the point where the maximum exposure rate was measured. The minimum time for receiving the annual allowable doses to the forearm and hand would be $3460 \mathrm{hr}$ and 8651 $\mathrm{hr}$, respectively. Therefore, it may be concluded that under normal conditions, handling of the XM829 ammunition does not present a significant radiological hazard.

Use of the basic dose reduction techniques of time, distance, and shielding, could further reduce the potential for personnel exposures to radiation from the XM829 ammiunition.

The XM829 shipping package studies satisfied all of the criteria specified in 49 CFR 173.421 and 173.424. Therefore, the package should be excepted from the specification packaging, marking, and labeling requirements of 49 CFR 173, provided that the inner or outer shipping package contains the marking "Radioactive."

Measured exposure rates from a 16-round pallet never exceeded $1.0 \mathrm{mR} / \mathrm{hr}$ at ariy surface point and all measurements were less than $0.2 \mathrm{mR} / \mathrm{hr}$ at a distance of 3 feet from the pallet. These values show that the storage of XM829 ammunition, even in a several pallet array, does not present a significant exposure hazard to personnel working in the storage area. 


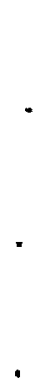




\subsection{REFERENCES}

ATTIX, F. H., W. C. Roesch, and E. Tochilin. 1969. "Radiation Dosimetry," Volume III, Academic Press, New York, San Francisco, London.

Bartlett, W. T., R. L. Gilchrist, G. W. Endres and J. L. Baer. 1979. "Radiation Characterization and Exposure Rate Measurements From Cartridge, 105-mm, APFSDS, XM774." PNL-2947, Pacific Northwest Laboratory, Richland, Washington.

Kathren, R. L., L. F. Kocher and G. W. R. Endres. 1971. "Thermoluminescence Personnel Dosimetry at Hanford." Am. Ind. Hyg.Assoc. J. 32(4):230-234.

Radiological Health Handbook. 1970. U.S. Department of Health, Education, and Welfare, Washington, D.C.

U.S. Code of Federal Regulations. 1982. Title 10, Part 20, "Standards for Protection Against Radiation."

U.S. Code of Federal Regulations. 1983. Title 49, Parts 170 - 189, Department of Transportation, "Hazardous Materials Regulations."

U.S. Code of Federal Regulations. 1983. Title 49, Part 173, "Shippers General Requirements for Shipments and Packagings."

U.S. Department of the Army and Defense Logistics Agency. 1982. "Medical Services - Control and Recording Procedures for Exposure to Ionizing Radiation and Radioactive Materials." AR 40-14, DLAR 1000.28, Washington, D.C. 

8.0 EXHIBITS 1 THROUGH 9 


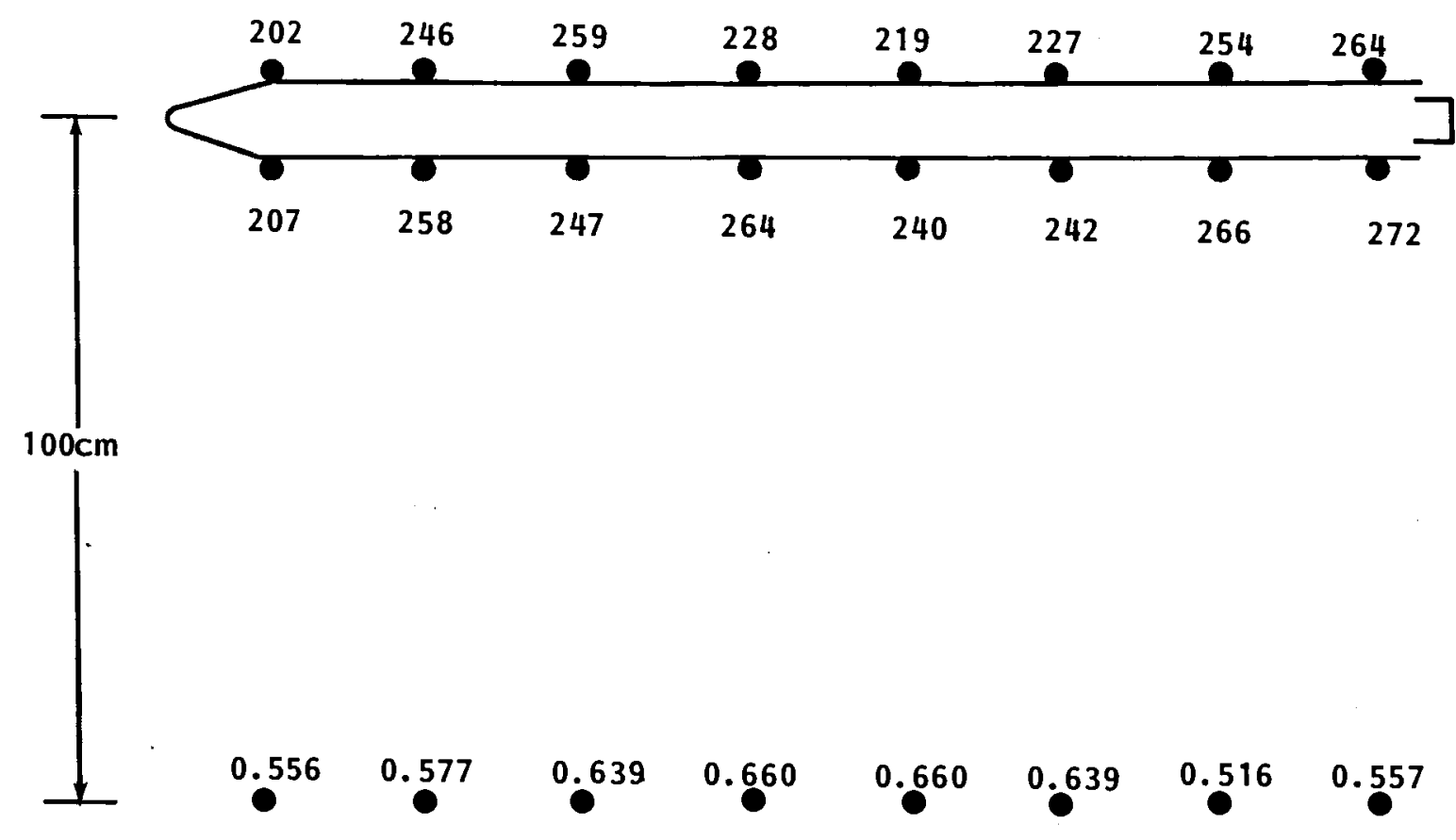

EXHIBIT 1. TLD Measurements (mrem/hr) of Bare Penetrator 


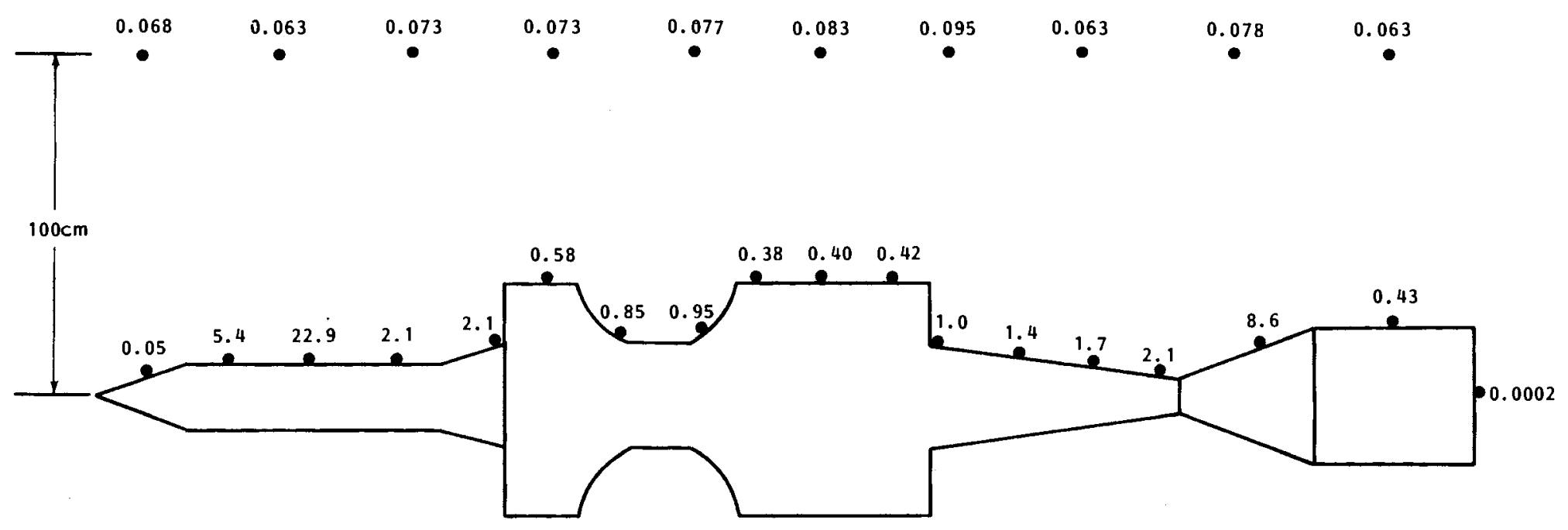

穴

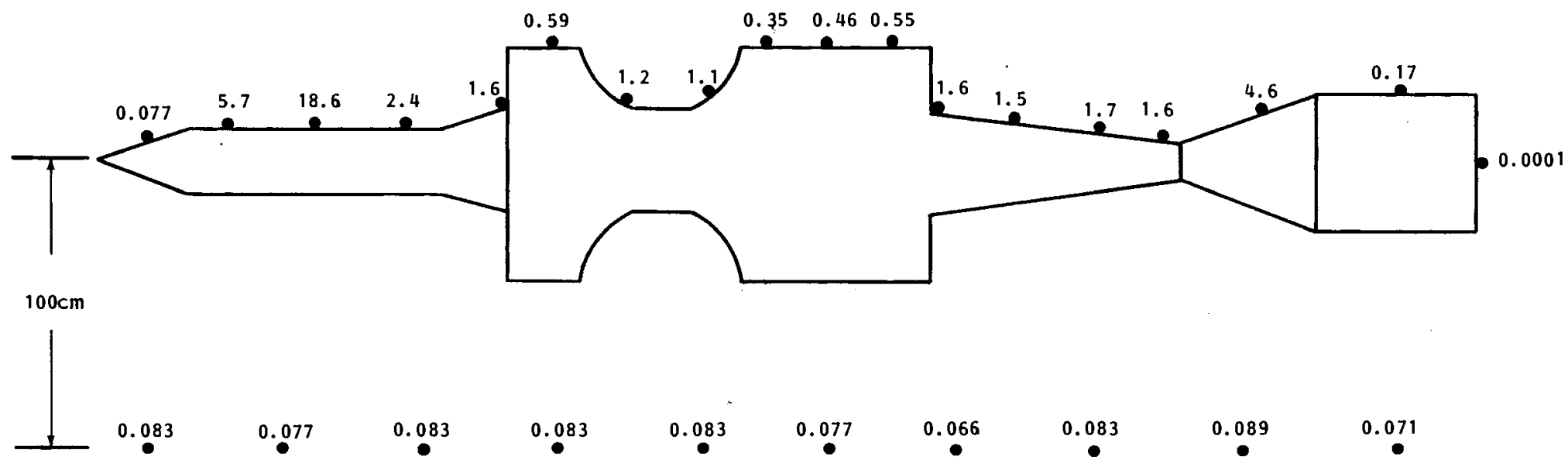

EXHIBIT 2. TLD Measurements (mR/hr) of Two individual Projectiles 


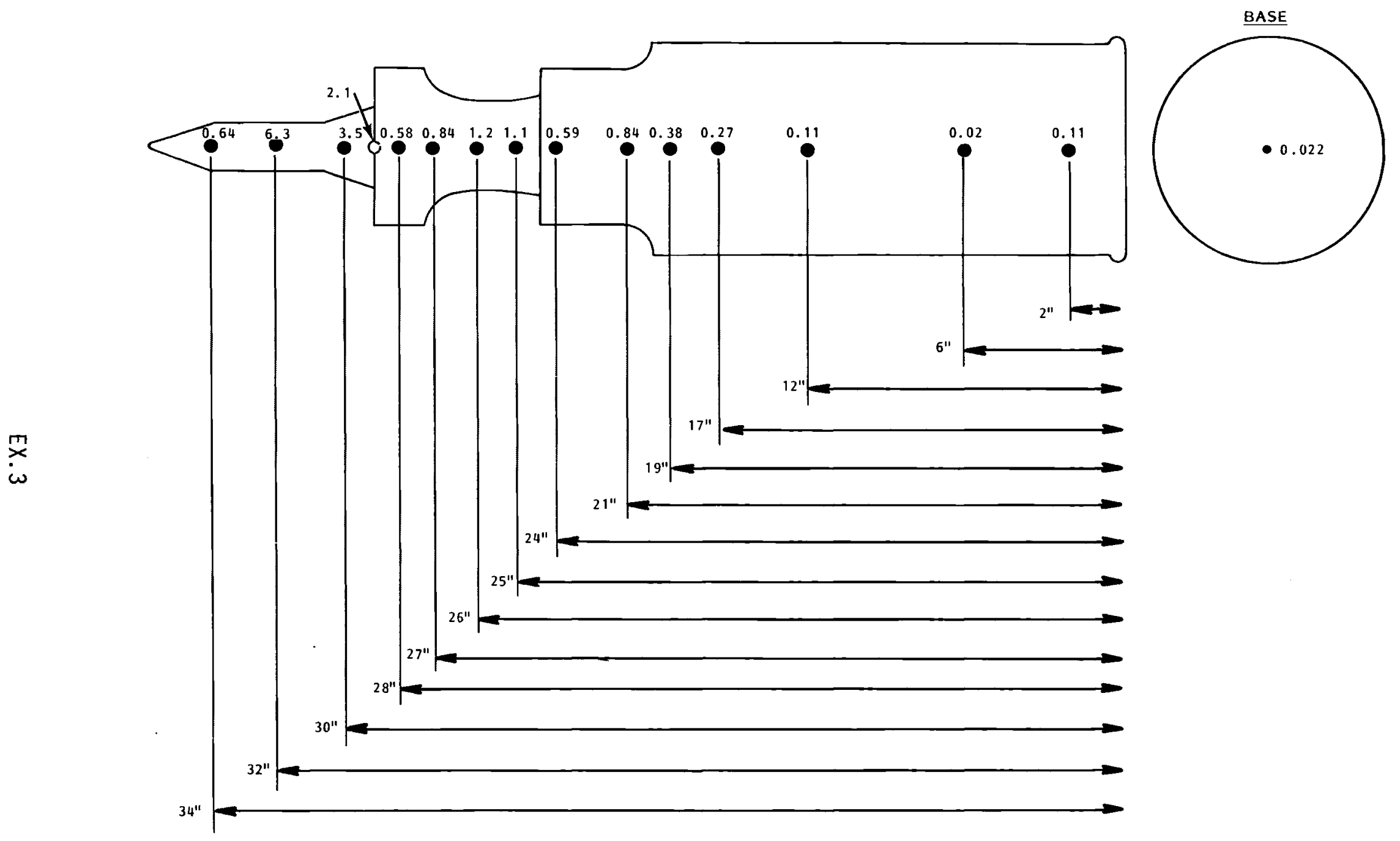

EXHIBIT 3. TLD Measurements (mR/hr) of Unpackaged Cartridge 
$\underset{0}{\stackrel{m}{\gtrless}}$
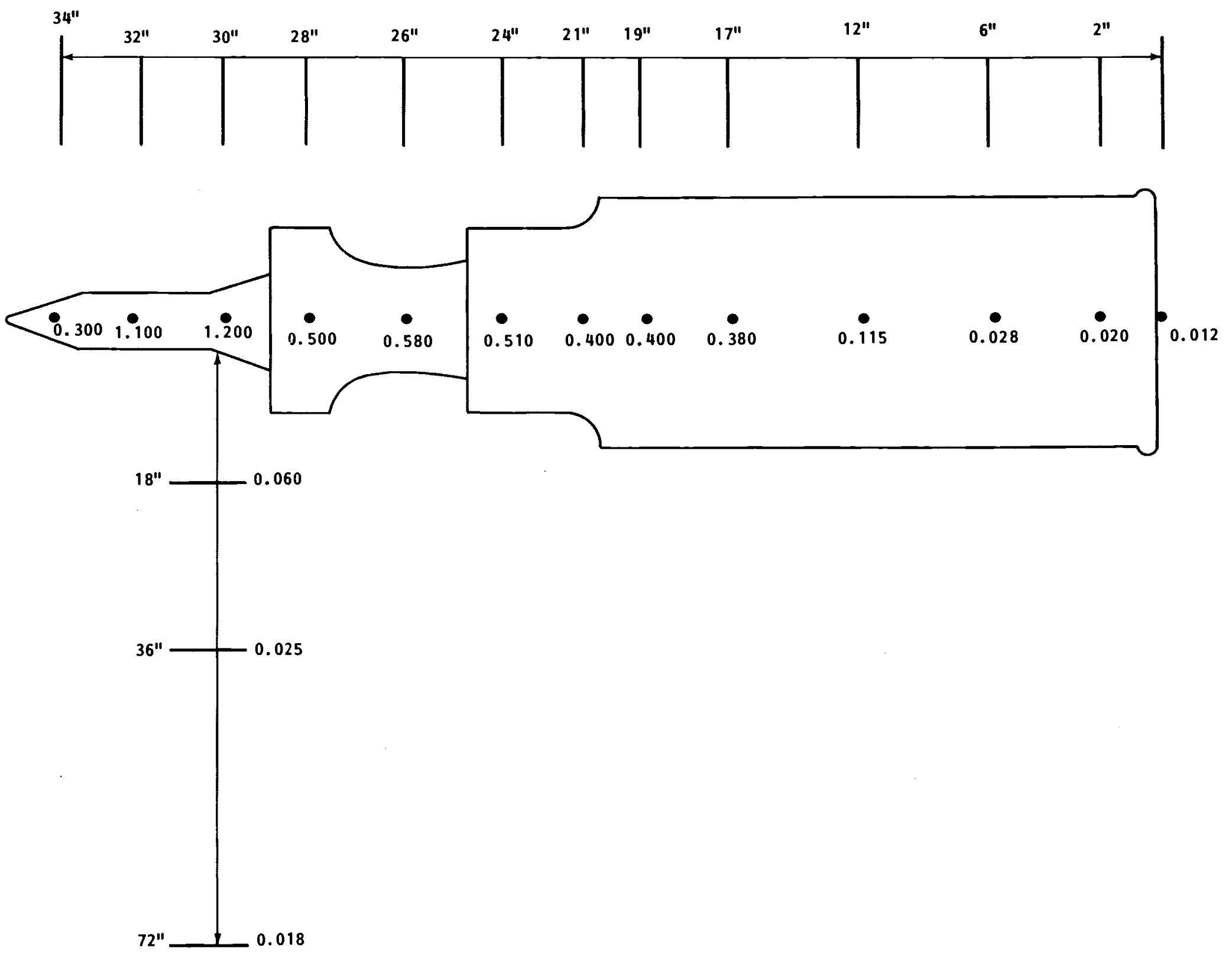

EXHIBIT 4. Micro-R Measurements (mR/hr) of Unpackaged Cartridge 
$m$
ir

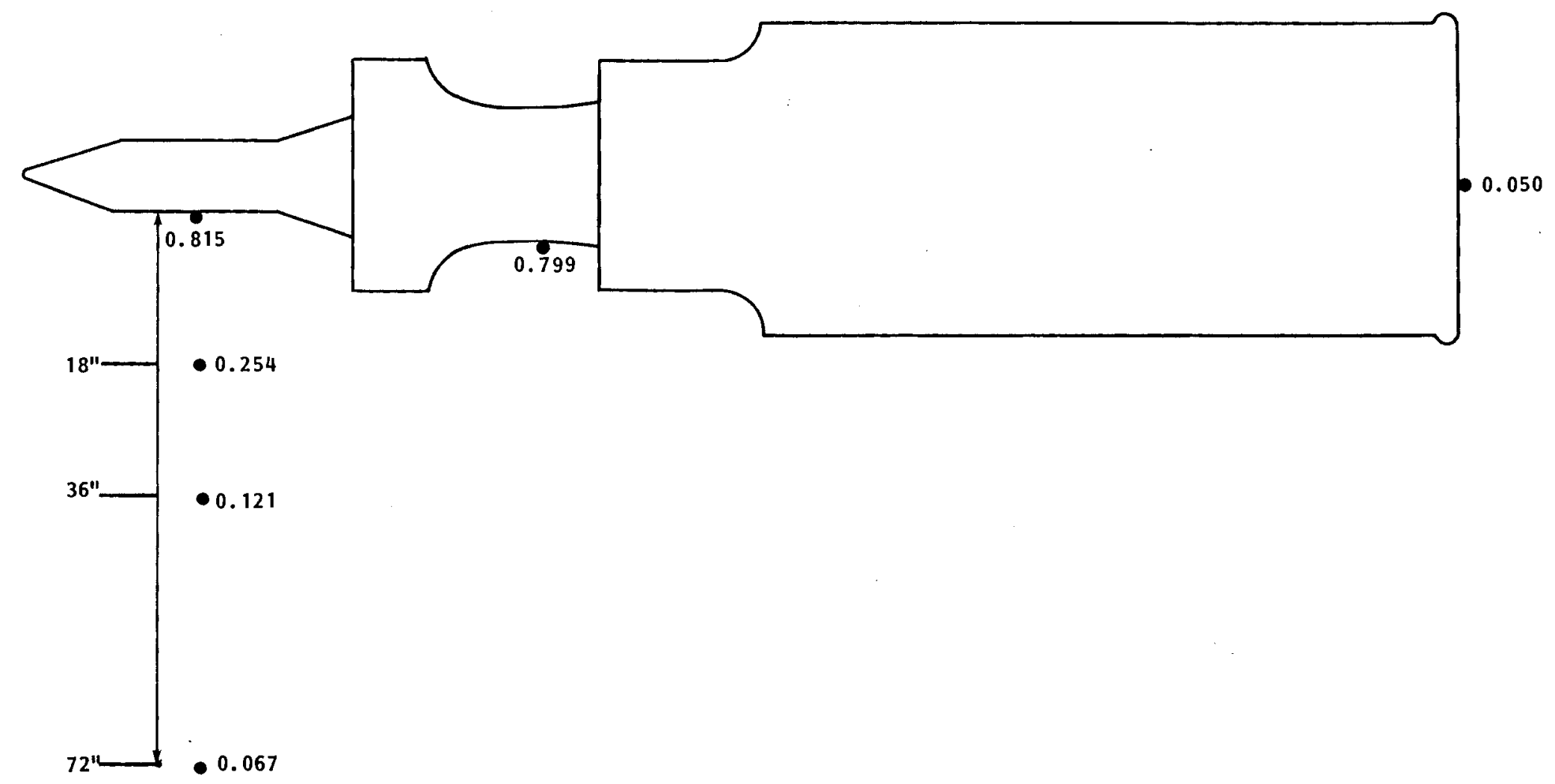

EXHIBIT 5. TASC-4 Measurements (mR/hr) of Unpackaged Cartridge 


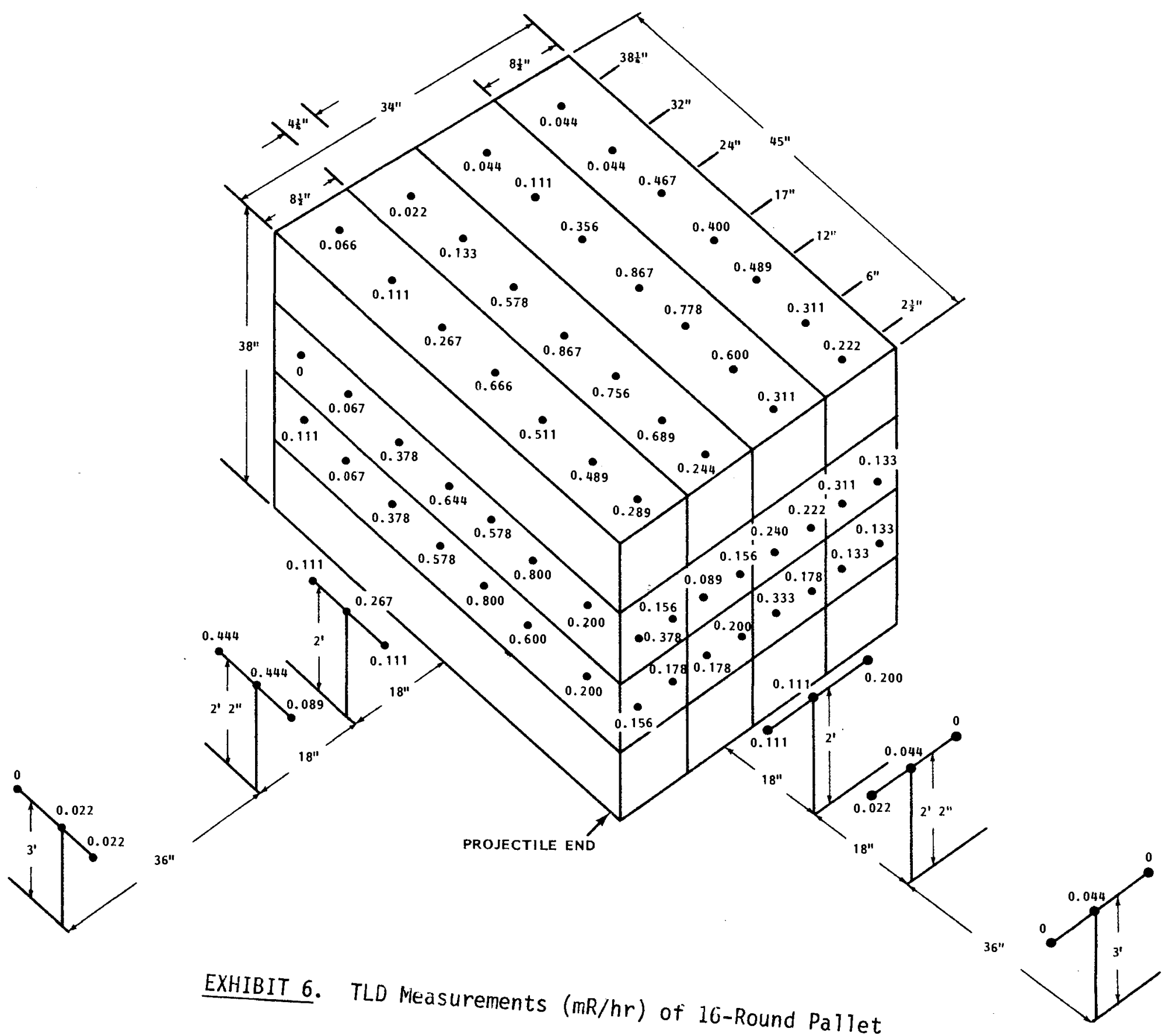




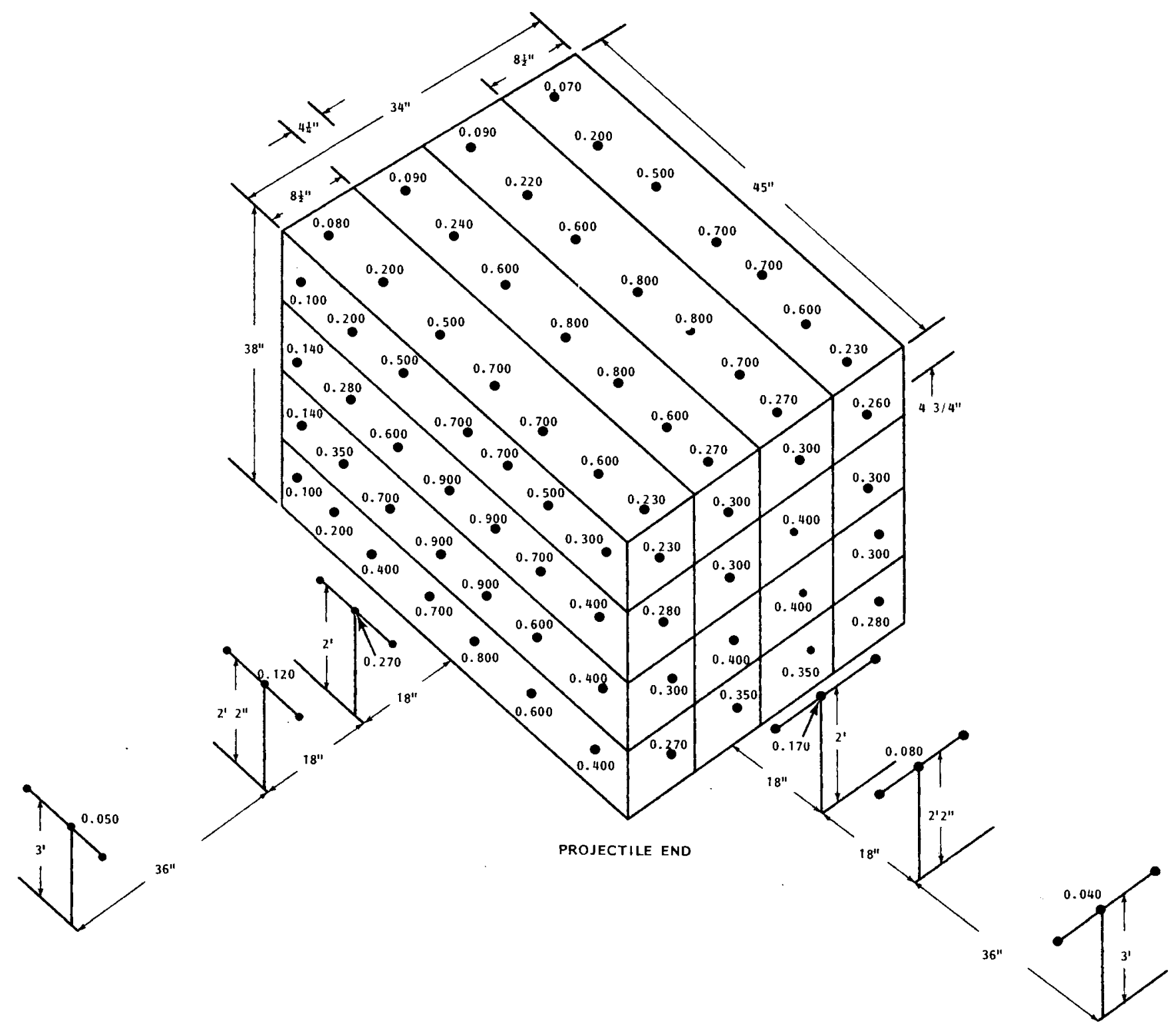

EXHIBIT 7. Micro-R Measurements ( $\mathrm{mR} / \mathrm{hr}$ ) of 16-Round Paliet 


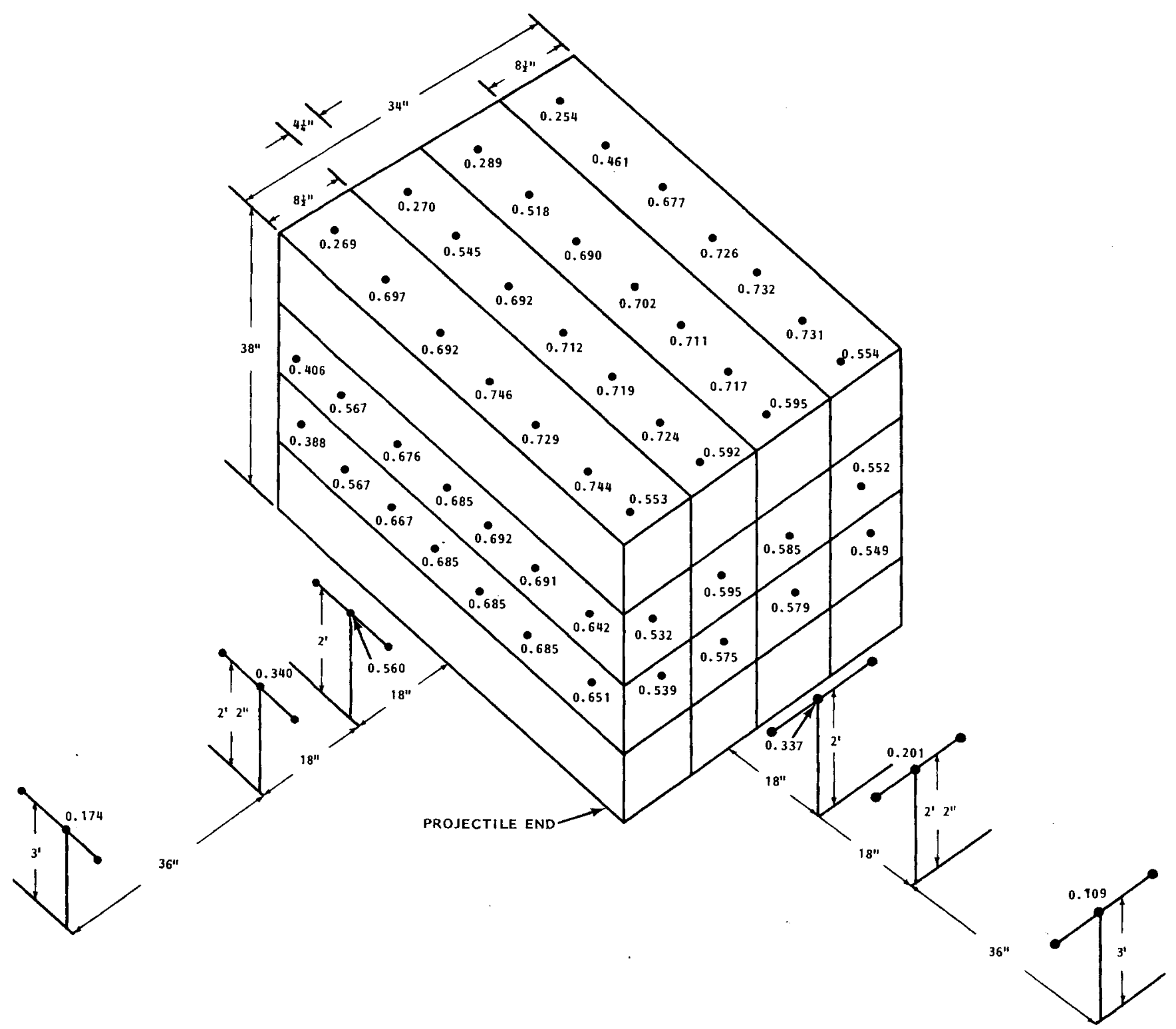

EXHIBIT 8. TASC-4 Measurements (mR/hr) of 16-Round Pallet 


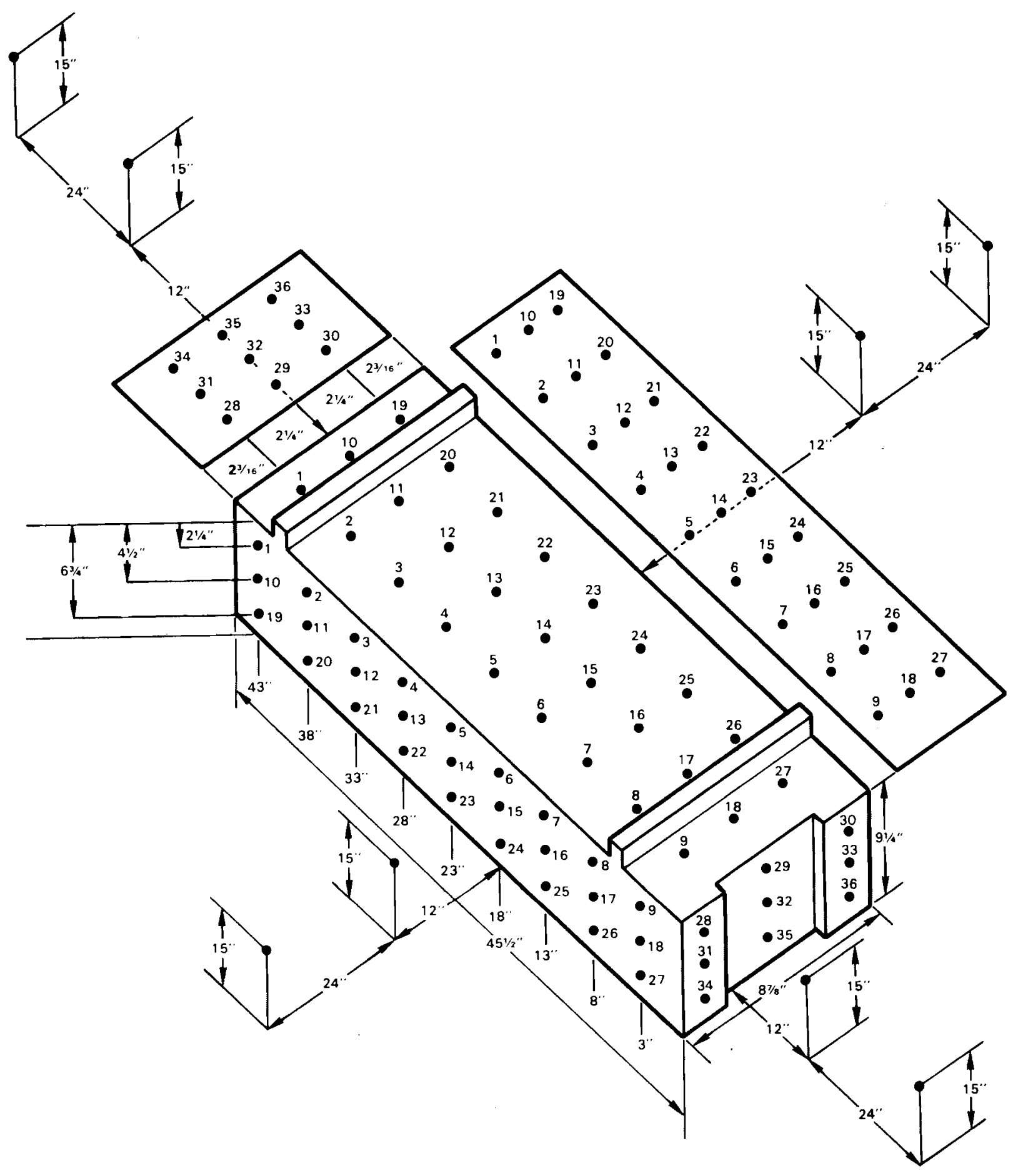

EXHIBIT 9. Portable Instrument Measurement Points on Shipping Container

EX.9 


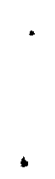




\section{DISTRIBUTION}

No. of

Copies

OFFSITE

AFMCO (OCSA)

Headquarters Dept. of the Army

ATTN: DACS-FM

Washington, D.C. 20310

9 CDR, DARCOM

ATTN: DRCSF -P

DRCSG-R

DRCDR-DW

DRCQA-P

DRCPA

DRCSF-E

DRXOS-ES

DROS-ES

DRCPM-PBM-FOI

5001 Eisenhower Avenue

Alexandria, Virginia 22333

Office of the Project Manager

Tank Main Armament System

ATTN: DRCPM-TMA-120

Dover, New Jersey 07801

2 CDR, USAEHA

ATTN: HSE-R

MSE-0

Aberdeen Proving Ground

Aberdeen, Maryland 21010

CMIDT USAMMCS

ATTN: ATSK-CD-CS

Redstone Arsenal, Alabama 35800

2 CDR, USAARMC

ATTN: ATZK-CD

$$
\text { ATZK-CG }
$$

Fort Knox, Kentucky 40121

Inspector General

Headquarters Dept. of the Army

DAIG-SD

Washington, D.C. 20310
No. of

Copies

2 CDR, AMCCOM

ATTN: $\quad \operatorname{DRSMC}-A S R(R)$

DRSMC-SF $(R)$

Rock Island, Illinois 61202

2 OASA

Headquarters Dept. of the Army

ATTN: SAIL-FM

SARDA

Washington, D.C. 20310

Commander

Aberdeen Proving Ground

ATTN: STEAP-TL

Aberdeen Proving Ground

Aberdeen, Maryland 21010

US Army Material Systems

Analysis Activity

ATTN: DRXSY-MP

Aberdeen Proving Ground

Aberdeen, Maryland 21010

Commander

US Army Materials \& Mechanics

Research Center

ATTN: DRXMR-X

Watertown, Massachusetts

02172

Commander

US Army Research Office

P.0. Box 12211

Research Triangle Park,

North Carolina 27709

Commander

US Army Foreign Science \&

Tech. Center

220 7th Street NE

Charlottesville, Virginia

22901 
Commander

US Army Tank-Automotive Materia] Readiness Command

ATTN: DRSTA-E

Warren, Michigan 48090

Commander

US Naval Ordance Lab.

ATTN: CODE WM

Silver Spring, Maryland 20910

Director

Air Force Materials Lab.

ATTN: AFML Technical Library

Wright-Patterson AFB

Dayton, Ohio 45433

Director

Air Force Weapons Laboratory

ATTN: Technical Information Division

Kirtland AFB, New Mexico 87118

ODSRDA

Headquarters Dept. of the Army ATTN: DAMA-CMS

Washington, D.C. 20310

ODPAE

Headquarters Dept. of the Army (ACS-DPA)

Washington, D.C. 20310

OCE

Headquarters Dept. of the Army (DAEN-ZCE)

Washington, D.C. 20310

OTJAG

Headquarters Dept. of the Army (DAJA-JA)

Washington, D.C. 20310

OCLL

Headquarters Dept. of the Army (SALL-PM)

Washington, D.C. 20310

Surgeon General

Headquarters Dept. of the Army (DASG-PSP-0)

Washington, D.C. 20310
2 CDR, TRADOC

ATTN: ATPR-HR-S

ATEN-FF-NR

Ft. Monroe, Virginia 23651

Chief

Bureau of Weapons

Dept. of Navy

ATTN: Technical Information

Division

Washington, D.C. 20025

Deputy Chief of Staff for

Research Development

and Acquisition

Dept. of the Army

ATTN: DAMA-ARZ-D

Washington, D.C. 20310

Ballistic Research Laboratory

ATTN: DRSMC-BLU

Aberdeen Proving Ground

Aberdeen, Maryland 21010

97 CDR, ARDC

ATTN: DRSMC-LCU-CT(D) (88)

DRSMC-SF (D)

DRSMC-SCM(D)

DRSMC-TDS (D) (5)

DRSMC-DAT (D)

DRSMC-LC (D)

Dover, New Jersey 07801

$3 \quad$ ODCSLOG

Headquarters Dept. of Army

ATTN: DALO-SMD

DALO-SMS

DALO-TSP

Washington, D.C. 20310

Chief of Public Affairs

Headquarters Dept. of Army (SAPA-PP)

Washington, D.C. 20310

27 DOE Technical Information Center 
No. of

Copies

$6 \quad$ ODCSOPS

Headquarters Dept. of Army

ATTN: DAMO-RQD

DAMO-SSM

DAM0-ODO

DAM0-TRS

DAMO-TRI

DAMO-SSA

Washington, D.C. 20310

General Counsel

Headquarters Dept. of Army (SAGC)

Washington, D.C. 20310

Director

Defense Ammunition Center \& School

ATTN: SARAC-AS

Savanna, Illino is 61074

3 CDR, TRADOC

ATTN: ATCD-S

ATCD-M-A

ATEN-FE

Ft. Monroe, Virginia 23651

CDR, MERADCOM

ATTN: DRME-VR

Ft. Belvoir, Virginia 22060

2 CINC USAREUR

ATTN: AEAGC-FMD

AEAGD-MM

APO New York 09403
No. of

Copies

ONSITE

DOE Richland Operations Office

H. E. Ransom

44 Pacific Northwest Laboratory

M. A. Eierdam

T. H. Essig

L. G. Faust

W. A. Glass

T. M. Graham

D. E. Hadlock

W. N. Herrington, III

G. R. Hoenes

C. D. Hooker (25)

J. Mishima

L. H. Munson

J. M. Selby

C. M. Unruh

Technical Information Center (5)

Publishing Coordination (2) 
. 